\title{
“Kampung Preman" Community Empowerment In Communicative Action Theoretical Study (A Case Study in Yogyakarta Indonesia)
}

\author{
Yuli Setyowati \\ Sebelas Maret University of Surakarta, Indonesia \\ Widodo Muktiyo \\ Sebelas Maret University of Surakarta, Indonesia \\ Mahendra Wijaya \\ Sebelas Maret University of Surakarta, Indonesia \\ Sarah Rum Handayani Pinta \\ Sebelas Maret University of Surakarta, Indonesia
}

\begin{abstract}
The establishment of communicative community in the context of "Kampung Preman" community can be seen from the community's communicative action, formerly living in violent and conflicting condition in contradiction with communicative community typology characterized with equal and harmonious relation. Through its communicative action, people (community) will change over time toward the guyub rukun communicative community. Therefore, this study on community empowerment viewed from communicative action is interesting as the history and characteristics of "Kampung Preman" community is very unique. This study aimed to analyze the process of empowering "kampong preman' community viewed from communicative action theory. This research was conducted descriptive qualitatively in Yogyakarta using case study. The data was collected using in-depth interview, observation, and documentation techniques. Data validation was carried out using source and method triangulations. Data analysis was conducted using an interactive model of analysis. The result of research showed that community's communicative action built on four claims according to Habermas' communicative action theory in empowerment process reveals the community's ability of driving them toward a life condition based on the mutually approved values and norms to control their own behavior or called self-regulation. Social groups function as public spaces for the community of express, thereby growing emancipation and solidarity among the communities.
\end{abstract}

Keywords: empowerment, community, action, communication

INTRODUCTION

Communication is the key to community empowerment highly supporting the acceleration of life quality improvement-oriented change (transformation). The achievement of community's autonomy and independency is inseparable from communication process. An effective communicative action is reflected from how the communication runs, so that the participants involved within it interact with each other in such a way in order to achieve a consensus. The development of high-quality human resource in some aspects of life is very desirable in an intended social change process. It is here that communication plays a strategic role in the attempt of making the society organize itself for the sake of mutual progress. 
Habermas (Hardiman, 2009) stated that community is essentially communicative, and it is learning process in practical-ethical dimension rather than merely production or technology power development that determines the social change. Technology and other objective factor can change the community if it integrates into communication action with its own logics.

Communicative action, according to Habermas (Hardiman, 2009) refers to the action directed to the mutually approved norms based on expected reciprocity between the subjects interacting with each other, using symbols, particularly daily language as the medium of taking such action. Communication is the starting point in this theory, and praxis is its central concept. Praxis is not defined as blinded behavior merely based on instinct but human's basic action as the social creature illuminated with rational consciousness. Ration is apparent not only in the activity of subjugating the nature through working, but also in intersubjective interaction using daily language.

There are four claims in Communicative Action Theory: (1) truth, the consensus on natural and objective world; (2) rightness, the consensus about the implementation of norms in social world; (3) authenticity (sincerity), the consensus about the compatibility between spiritual world and an individual's expression; and (4) comprehensibility, the ability of explaining the claims above and achieving the consensus on it. Any effective communication should achieve the fourth claims and people that can communicate, in the sense of producing such the claims, have "communication competency".

Habermas defines communicative society as the one criticizing through argumentation rather than revolution or violence, as characterized with autonomy and maturity. There are two types of argumentation: discourse and critique. Discourse is done through presupposing the possibility of achieving a rational consensus. Meanwhile, critique is made when communication is disturbed, thereby unnecessarily presupposing consensus. In participative society development, both of them are needed in formulating and accomplishing the objective and targeted activity plan more appropriately (Santoso, 2014).

To comprehend the society's communicative action today, a understanding of "public space" concept is required. "Public space" is a concept becoming popular in social sciences, democratic theories, and other discourses currently. This concept speaks of democracy in a complex society in globalization era. Habermas (2015) explains that public space plays an important part in democratic process. Public space is a democratic space or society discourse medium, in which the citizens can express their opinions, interests and needs discursively. Public space should be autonomous, without government's intervention. Public space is the citizens' media of communicating, discussing, arguing, and taking stance against problems. Public space serves not only as legal institution or organization, but also as the communication between citizens.

Habermas divides public space, where the society actors and citizen build public space, into four: 1) as plurality (family, informal groups, voluntarily organizations); 2) publicity (mass media, cultural institutions, and etc); 3) privacy (individual and moral development area); and 4) legality (general legal structures and basic rights). Thus, many public spaces exist amid the citizen community. Where society communicates and discusses relevant themes, there the public space will be present. Public space is free and unlimited, not bond to market interests and political interests (Habermas, 2015). Habermas defines "public sphere" as our social life area in which public opinion is created. Access to public sphere is opened to every citizen. Some of public spaces are created in any discussion in which individuals assemble to create a "public". When the public is getting large, this communication requires a means of 
disseminating and influencing; today, newspaper and magazine, radio and television become the public sphere media. Communicative media becomes dialog medium. From this definition, it can be stated that public sphere is not only physical space but also social space produced by communicative action. In public space domain (polis), citizenship and sense of belonging dealing with family scope (oikos) and local relationship (Sastrapratedja in Hardiman, 2010).

In the process of society change and independence, public sphere can be understood as the learning space as the manifestation of social relation process between society members. Soetomo (2012) stated that in social relation process, collective action rather than individual action occurs. Collective action contains collectivity element, thereby requiring energy that can drive cooperation. This collective action is done to meet common needs and interests facilitated by social institution and oriented to the mutually approved rule. The result of collective action is the development and improvement of social institution ability, local knowledge, and objective achieving mechanism. All of those impact on the improvement of sustainable society capacity.

The study on "Kampung Preman" community empowerment, based on communicative action theory, in this case, is supported with social construction theory of reality and symbolic interactionism. Communicative action is inseparable from social process through action and interaction in which individual creates a reality shared and experienced subjectively.

\section{PROBLEM STATEMENT}

A society living in "kampung preman" stigma is often perceived as the one changing difficultly. Nevertheless, the phenomenon occurring in Yogyakarta is different, in which "kampung preman" community has changed very significantly because of the community empowerment attempt initiating by society leaders and supported with CSR program. Community empowerment process can be seen from its community's communicative action. Therefore, the problem of research is "how is the "kampung preman" community empowerment process viewed from communicative action theory?"

\section{METHOD}

This study on "kampong preman" community empowerment used a descriptive qualitative research. A descriptive qualitative research will be able to capture a variety of qualitative information with thorough and nuanced description (Soetopo, 2006). The research strategy used was a single case study because this research focused on the target with a characteristics existing in one location (Yin, 1987). Because the problem and focus research has been determined earlier, this case study research strategy can be called an embedded case study research (Soetopo, 2006). Creswell (1998) also states that case study focuses on a case specification in an event, involving individual, cultural group or life portrait.

The data of research was collected using in-depth interview, observation, and documentation methods. Informants were selected using purposive sampling technique. Observation was conducted to obtain data on situation, location and events observable. Meanwhile, documentation is used to document empowerment activity conducted in kampung Badran.

\section{RESULT AND DISCUSSION}

A society's social change occurs when there is its members' willingness to abandon their old cultural and social system and to turn to using new cultural elements and social system. Social change is considered as the concept involving entire society life at individual, group and society levels (Bungin, 2006). The experience of Kampung Badran people who have long lived 
with "kampung preman" stigma leads them to a consensus to abandon their old way colored with violence, low education level, low economic level, slump area impacting on the people's health, and social relations often colored with conflict. After the society has realized that they cannot live in such the condition continuously, they agree to build new ways of living within family and society by "building shy culture". Shy culture is the Kampung Badran's new way of escaping from the life replete with dark side. Community empowerment through "building shy culture" has started with society leader encouraged to promote its kampong. Although the community's resistance is sufficiently high, this attempt can be stated as fairly effective.

In the attempt of "building shy culture", communication aspect becomes very essential. The groups existing in society are used as the forum to communicate new ways or culture to get out of stigma as "kampung preman". The communication conducted can be the means of building inter-individual and inter-group relation. In this relation, an understanding on their work is constructed gradually on their world so far and that opens the insight into better condition of world. Ruben and Stewart (2013) stated that communication is essential to individual, relation, group, organization, and society. Communication is a line connecting human to world; it is human beings' means of expressing themselves and influencing others, and creating an image about and to the world. Therefore, when human beings do not communicate, they can create and maintain their relationship with each other in group, organization, and society. So, communication enables human beings to coordinate all of needs with and along with others.

In the attempt of explaining communication conceptualization in convergence perspective, Miller (2002) suggests that communication can be seen from three aspects: (1) communication is a process, (2) communication is transactional, and (3) communiction is symbolic.

Communication is a process, meaning that communication is a process in which every event and relation occurs is dynamic, ongoing, always changing, and sustainable. The Kampung Badran people's changing process reveals that the society dynamics is a very influential factor. Inter-individual relations occur very dynamically within it. The relations established can drive the society into a motivation of changing. Until today, this process is still well-maintained.

Communication is transactional, seeing that communication is an interaction process in which inter-participant communication participates actively, reciproclaly, speaking, responding, acting, and reaction, and interdependent. Considering the result of research, the good communication process, both formal and informal, can respond to a very wide space for the participants to participate actively, to give each other and to give feedback with good argumentation. In such the communication process, participants affect each other through speaking (conversation) they make. The way of responding to others' speech seems to be respectful and constructive, despite often containing critique. It may occur, inseparable from the leader's role. In such the condition, people become accustomed to convey action and reaction positively.

Communication is symbolic, meaning that communication process involves interrelated symbols, either verbal or nonverbal. In cognitive perspective, Colin Cherry (Bungin, 2006) states that communication is the use of symbols to achieve the shared meaning or to share information on an object or event. The meaning contained in verbal symbol is particularly apparent in daily language use. The change of mindset and behavior is reflected on daily language use. Nonverbal behavior reflected on body language, voice intonation, and facial expression automatically changes with the dynamic society character change. It is in line with Barbara Ballis Lal (Littlejohn \& Foss, 2008), in symbolic interactionism concept, stating that: (a) human beings make decision and act according to their own subjective understanding on 
situation when they find themselves; (b) social relation consists of interaction processes, thereby always changing; (c) human being understands their experience through the meanings found in the symbols of their main group and language is an important element of social life; (d) world is composed social object with socially defined name and meaning; (e) human action is based on their interpretation, in which object and action is related in the situation considered and interpreted; and (f) self is a significant object and just like other all social objects, is introduced through social interaction with others.

The establishment of social groups in "kampung preman" Yogyakarta is the public space that can be inter-citizen communication space, although until today there are still many communication spaces requiring optimization in order to function better. Social groups in Kampung Badran, according to Habermas, are a public space for community to express and to communicate all of their ideas or thoughts. Through communication in the public space, the community experience learning process as the part of social process between society members. This learning process conditions individual to cooperate, thereby creating collective action. It is in line with Sutomo (2012) suggesting that in social relation process, collective action rather than individual action occurs. Collective action contains collectivity, thereby requiring energy that can activate cooperation. This action is taken to realize the collective need and interest facilitated by social institution and oriented to the mutually approved rule. The result of such the collective action is the development and improvement of social institution ability, local knowledge, and objective achievement mechanism. All of these impact on the sustainable society capacity improvement.

In the context of "kampung preman" people, the existence of social groups is very effective for community empowerment media. In social groups, more dialogical communication occurs between its members. In the presence of dialogical communication, group members have opportunity of appreciating each other, understanding others' existence, and growing collective consciousness. In addition, social discrepancy between communities is reduced gradually through the establishment of social group solidarity as a result of collective consciousness. Friedmann (in Nasdian, 2014) mentions that social group is the most effective container for community empowerment enabling individual to organize itself in the group (collective self-empowerment). It is in this group that dialogical encounter growing and confirming group consciousness and solidarity will occur. In this case, the members of group grow uniform identity and identify their mutual interest.

The behavior of every individual in groups is not something standing alone, but a form of action affected by its environment. The behavior of Kampung Badran people in the past and in the present is the form of behavior resulting from learning process in its social system. Talcott Parsons (Ritzer, 2003) in Action Theory, a part of Social Construction theory, states that every individual can be related to its social system through its status and role, in which each individual has status and role in its social sistem, according to the rule or norm within it. The behavioral changes experienced by Kampung Badran's community leads to its status change, either social or economic, and role within society.

The effect of communication in social groups in "kampung preman" on its community behavior is substantial. From the result of interview and observation, it can be seen that the community's response to the participation in social groups is very high. An individual can join 4 or 5 or more social groups. They highly enjoy the activity of groups followed. Thus, the interaction occur in group highly affects the behavior of its members. The role of cadre as facilitator in every group is very effective. They communicate positive things incessantly for 
the sake of its community members' character change. It is just like what can be understood through Action Theory, stating that reference group plays an important part used as individual reference to adjust their behavior with the society norm, and even reference group can be reference for individuals not belonging to a social group's member to identify itself with the group. Human behavior is the result of experience and interaction with environment thereby producing knowledge, attitude and action. Individual behavior is a response to stimulus coming from either outside or inside itself having passing through thinking process and in the form of visible behavior (Soekanto, 1990).

In every communication process occurring in social groups and in daily inter-individual communication, every individual can be the subject for itself. Each individual interprets any message or information communicated with other individual independently. The process of interpreting its own action reflects that individual is subject for itself and its world. Every individual has ability of building or constructing its social reality. In social Construction theory, Peter L. Berger and Thomas Luckman explain that social reality is a social construction coined by individual. Individual is human being establishing inter-human relationship independently (freely) and becoming the determinant of social world constructed based on its will. Individual is not a victim of social fact but as production media and creative reproductive all at once in constructing its social world (Basrowi dan Sukidin, 2002).

Social construction of reality concept is defined as a social process through action and interaction in which individual creates continuously a reality shared and experienced collectively and subjectively (Poloma, 2004). From the result of study, the phenomena can be captured clearly when the society is involved in group encounters. The encounters held become a very dynamic collective reality as each of individuals expresses their opinion freely based on their own point of view. Community member has been accustomed with selfpositioning, for example, in formal forum they will behave and argue formally, while in non formal encounter, their behavior and speech will be relaxed without partition hindering them to communicate, despite different social and economic statuses. Their communication is egalitarian. It seems to be inseparable from their life background so far. Frank and straightforward speech is the typical characteristic of "kampung preman" people.

In symbolic interactionism, according to Blumer (Poloma, 2004), actor not merely reacts to others' action, but also tries to interpret and defines every others' action. It is because of the presence of "self". In interacting, one individual and another are mediated by the use of interpreting symbols, language. The symbol interpreting action by individual will give meaning, asses its compatibility to action, and make decision based on such the assessment. Therefore, in interaction within "kampung preman people", individual involved is the conscious and reflective actor as it acts according to interpretation, meaning that individual acts on based on ratio and deliberation. Blumer, then, called this concept "self indication", the communication process running; in this process, individual knows something, assesses, gives meaning, and decides to act on. It is this process as well that enables individual to anticipate others' action and adjusting its action just like how it interprets this action.

Empowerment attempt that has been done in "kampung preman" is a long process until today, but change by change has been observable. "Kampung preman" formerly seemed to be terrifying, now changes into a much opened kampong. Its community has experience character change considerably, in mindset and behavior; even particularly in RW 11, there are many community activities that can bring about many changes in education, health, and productive economic sector. This kampong has been visited by other areas frequently to be comparative study site, particularly relayed to rubbish bank. 
In time process, the change of community character, formerly living with "kampung preman" stigma, experiences dynamics in its communication action. The form of communication used utilizes more interpersonal communication. Although this community belongs to urban areas, but its communication action characteristics reflect more on the communication action upholding kinship, solidarity, and empathy. Daily life as the communicating symbol currently is a more ethical language, meaning language not containing violence and capable of building a community life harmony. As Habermas (Hardiman, 2009) suggests, communicative action is directed by mutually approved norms based on reciprocal expectation between the subjects interacting using symbols, particularly daily life as a medium of action. In this case, language in communication becomes a very important element to yield certain communicative action. This communicative action arises as the result of inter-subject interaction corresponding to the consensus between subjects.

As Hubermas (Hardiman, 2009) states, the community is essentially communicative and what determines social change is not only the development of production or technology power, but also learning process in practical-ethical dimension. Technology and new other objective factor can change the community if it integrates into communicative action with its own logic. The phenomenon of "kampung preman" people reveals that in the last 10-15 years, they experiences collective learning process that in turn leads to change by change. In such the learning process, they communicate, receive and send message or information to each other, and then integrate it into communicative action through a shared daily language.

Claim of truth in the communicative action of "kampung preman" people can be seen from the community consensus stating that their condition will change naturally. They cannot survive with old life system, meaning that they are highly aware that they should change naturally as the time changes. Many nasty experiences they encounter when they live in "kampung preman" stigma. Therefore, the community achieves consensus collectively to get out of "kampung preman" stigma. Such the approval will be realized when there is action collectivity in the community. The collectivity (commonness) to be a new community condition creates new structure and values as well.

Claim of rightness can be seen from the consensus about the implementation of new norms and values in the community. "Kampung preman" life colored with gambling, drinking, domestic violence, abuse, and emotionality habits as if has been the values and norms considered as suitable. However, after the religion and education values have been stronger in Kampung Badran, those habits vanish gradually and are replaced with more cultured and ethical norms and values.

When community's mindset and behavior have changed, it will result in the changing community structure as well. New community (society) structure is colored with new values. In the context of Kampung Badran's people, those new values are related to education, health, and family economy aspects, the benefit of which can be felt directly by family specifically and in broader scope the benefit can be felt by the community. It can automatically affect spiritual world of community and will be expressed in daily life. It is here that the claim of sincerity can be seen.

Claim of comprehensibility can be seen from the enactment of truth, rightness and sincerity claims in a community. It can be seen from communicative action of "kampung preman" community. Today, the community has been accustomed with the changing condition, related 
to physical, social, and cultural condition. The change of its community's physical, social, and cultural condition becomes interdependent in a sufficiently long process.

In the process of changing "kampung preman" people, women and family play a very considerable part. Women become the entrance to various communicative messages containing important information related to the spirit of change buzzed. Information obtained from various social group forums are forwarded to individual families and smaller forums in their areas. The more frequently the information is delivered, the more embedded is the information into those hearing it, and then they interpret based on their own experience. The result of interpretation on the message received results in new action. When in the family there is a role model of change, it will impact on the change within other members of family very effectively. In this context, communication can be considered as a dynamic, transactional and symbolic process.

Communicative action in community empowerment based on those consensuses basically leads to the improvement of community life quality in various aspects. It is confirmed by Mardikanto (2010) stating that the objective of empowerment is to improve the quality of community life involving some aspects. The improvement of life quality can be accomplished through: (a) better education; (b) better accessibility; (c) better action; (d) better institution; (e) better business; (f) better income; (g) better environment; (h) better living; and (i) better community. The better life condition supported with better physical and social environment is expected to bring the better community life into reality. Considering the objectives of empowerment, the ultimate objective of community empowerment activity is the better realization of changes, from individual, family, community to environment level, so that finally community independency results.

Community independency and sustainability can be maintained and developed in guyup rukun (harmonious) community circumstance. Guyub rukun is a Javanese terminology deriving from the original word guyub meaning the willingness to be together in commonness or in other words the commonness in working on everything together. Meanwhile the word "rukun" means harmony, without dispute or avoiding dispute. If dispute or conflict occurs, it can be resolved through discussion and consensus with the spirit of commonness (Yuliana Lestari in http://www.kompasiana.com/www.login.kompas.com/dibalik-makna-guyub-rukun).

Guyub rukun is a community difficult to find currently, moreover in urban community. Most guyub rukun characteristics can be found in rural community, particularly in still natural village, the one that has been eroded by the community behavior change due to time and technology advances. For example, when a family is holding an event or is experiencing misery because one of its members dies, without invitation, the neighbors will come to give any help, in the form of effort, food material, fund, advice or thought. Even, when they do not give help (cawe-cawe), they will feel being guilty. Meanwhile in urban community, the prominent characteristics is individualism and uncaring.

Guyub rukun community in this research is characterized by the community's way of maintaining kinship, gotong royong (Indonesian original term meaning mutual cooperation to achieve the mutually expected result), inter-citizen solidarity, tolerance between religion communities, not discriminating social-economic status, and being proud of their kampong. Being proud of their kampong encourages the high sense of belonging their kampong. Those dimensions of guyub rukun are the community's social capital very desirable to community empowerment. The guyub rukun community condition will remove the partitions of communication due to the social gap existing within society. The guyub rukun community is the 
very specific type of communicative community corresponding to the very unique characteristics of community, just like "kampung preman" people.

\section{CONCLUDING REMARK}

Communicative action of community, based on four claims according to Habermas' communicative action theory in empowerment process, reveals the presence of community's ability of driving them toward a life condition building on the mutually approved values and norms to control their own behavior or called self-regulation.

The social groups function as public spaces for the community to express itself, thereby growing emancipation and solidarity within society. Social group is the most effective empowerment medium at community level enabling the individuals to organize themselves in the group (collective self-empowerment). It is in this group dialogical encounter growing and confirming the group consciousness and solidarity will occur.

\section{References}

Basrowi and Sukidin. 2002. Metode Penelitian Perspektif Mikro: Grounded Theory, Fenomenologi, Etnometodologi, Etnografi, Dramaturgi, Interaksi Simbolik, Hermeneutic, Konstruksi Sosial, Analisis Wacana, dan Metodologi Reflektif. Surabaya: Insan Cendekia.

Bungin, Burhan. 2006. Sosiologi Komunikasi. Teori, Paradigma, dan Diskursus Teknologi Komunikasi di Masyarakat. Jakarta: Kencana Prenada Media Group.

Creswell, John W. 1998. Qualitative Inquiry and Research Design: Choosing Among Five Tradition. London: SAGE Publications.

Habermas, Jurgen. 2015. Ruang Publik. Sebuah Kajian Tentang Kategori Masyarakat Borjuis. Penerjemah: Yudi Santoso dari judul asli The Structural Transformation of the Public Sphere: An Inquiry into a Category of Bourgeois Society. Bantul: Kreasi Wacana.

Hardiman, F. Budi. 2009. Menuju Masyarakat Komunikatif. Yogyakarta: Penerbit Kanisius.

Hardiman, F. Budi (editor). 2010. Ruang Publik. Yogyakarta: Penerbit Kanisius.

Littlejohn, Stephen W\& Foss, Karen A. 2008.Theories of Human Communication. Edisi 9. Belmont USA: Thomson Wadsworth.

Mardikanto, Totok. 2010. Komunikasi Pembangunan. Acuan bagi Akademisi, Praktisi, dan Peminat Komunikasi Pembangunan. Surakarta: Sebelas Maret University Press

Miller, Katherine. 2001. Communication Theories. Perspectives, Processes, and Contexts. New York: Mc Graw Hill. Poloma, Margareth. 2004. Sosiologi Kontemporer. Jakarta: Raja Grafindo Persada.

Ritzer, George - Goodman, Douglas J. 2008. Teori Sosiologi Modern. Edisi Keenam. Dialihbahasakan oleh Alimandan. Jakarta: Kencana Prenada Media Group.

Ruben, Brent D \& Steward, Lea P. 2013. Komunikasi dan Perilaku Manusia. Edisi Kelima. Terjemahan Ibnu Hamad dari buku Communication and Human Behavior (Fifth Edition). Jakarta: RajaGrafindo Persada.

Santosa, Imam. 2014. Pengembangan Masyarakat Berbasis Sumber Daya Lokal. Yogyakarta: Pustaka Pelajar.

Soekanto, Soerjono. 2013. Sosiologi Suatu Pengantar. Jakarta: Raja Grafindo Persada.

Soetomo, 2012. Keswadayaan Masyarakat. Manifestasi Kapasitas Masyarakat untuk Berkembang secara Mandiri. Yogyakarta: Pustaka Pelajar.

Yin, R.K. 1987. Case Study Research: Design and Methods. Beverly Hills, CA: Sage Publication. 